\title{
INJURIES IN PRESCHOOL CHILDREN AND THE POSSIBILITIES OF THEIR PREVENTION
}

\author{
Ivon Matić ${ }^{1}$, Jelena Kovačevićc ${ }^{23}$, Ivan Miškulin², Nika Pavlović́ ${ }^{2}$, Maja Miškulin ${ }^{2 *}$ \\ ${ }^{1}$ Županja Health Center, Županja, Croatia \\ ${ }^{2}$ Josip Juraj Strossmayer University of Osijek, Faculty of Medicine Osijek, Osijek, Croatia \\ ${ }^{3}$ Institute of emergency medicine of the Vukovar-Srijem County, Vinkovci, Croatia
}

Rad je primljen 18.07.2021. Rad je recenziran 26.07.2021. Rad je prihvaćen 09.08.2021

\begin{abstract}
INTRODUCTION: Injuries in preschool children are one of the leading causes of child's morbidity and mortality in today's world.

OBJECTIVE: Explore the prevalence and the type of injuries in preschool children as well as the parental behavior regarding injury prevention and to investigate the interconnections between these variables.

SUBJECTS AND METHODS: The cross-sectional study included 218 parents of preschool children from the Županja area, in Eastern Croatia, who filled out an anonymous questionnaire during the April of 2015 that consisted from questions regarding sociodemographic and socioeconomic indicators related to the family and the participant's behavior regarding injury prevention.

RESULTS: There were $30.3 \%$ of the participants whose preschool children suffered an injury and $86.4 \%$ of those suffered a minor injury. In most of the examined parental behaviors, parents have shown adequate accident prevention behavior, while in the three examined behaviors (the existence of a security barrier that prevents access to the stairs, the existence of a security barrier that prevents access to the windows and the installation of smoke detectors) parents have shown inadequate behavior which indicates the need for their additional education.

CONCLUSION: This study can serve as a database for future investigations of accidents of preschool children and the possibilities of their prevention. Additional studies are needed to understand parental behavior in relation to the prevention of their children accidents.

Key words: injury, preschool children, parents, prevention, Croatia

Corresponding author:

Professor Maja Miškulin, MD, PhD, specialist in epidemiology and health ecology

Josip Juraj Strossmayer University of Osijek

Faculty of Medicine Osijek, Josipa Huttlera 4, 31000 Osijek, Croatia

Tel.: +385 912241 438, E-mail: maja.miskulin@mefos.hr
\end{abstract}




\section{INTRODUCTION}

Injuries in preschool children are one of the leading causes of child's morbidity and mortality in the world and they are also the growing public health problem especially in developing countries and highly developed countries, why they require greater attention from the medical profession for their possible reduction (1-5). The current epidemiological situation of children's accidents in the world is similar to Croatian, with children's accidents being the leading cause of child death after the period of infancy. By the 1960, the rate of children's accidents up to 14 years of age was $24.2 \%$, rising to $50.9 \%$ by the 1990. Risk factors today are numerous, such as lower socioeconomic status, poor relationships within the family, greater number of family members, single parent/guardian, little or no investment in child safety, family stress, lack of educational health programs and failure to implement a health promotion program on local and national level $(6,7)$. Another significant factor in the prevention of accidents in preschool children is the parents' behavior regarding the circumstances that may cause or prevent children's accidents - prevention measures $(2,3,5)$. Parents of preschool children generally use three safety practices: teaching children about specific rules, modifying the surroundings to eliminate hazards and supervising. In prevention of injuries indoors, some strategies are more effective than others. It is crucial to recognize how many hazards cannot be removed and that supervision is fundamental. Older preschool children are more sovereign and therefore less supervised (8). Zhou et al. (2019) stated that in order to improve child safety behaviors and mitigate unintentional injuries among Chinese preschoolers, their parents' safety rules are beneficial due to their major role (9).

As part of the prevention of accidents in all children, the role of the whole society in health education and health promotion programs at health centers and schools is crucial. UNICEF's prevention model divides prevention options into primary (prevention of new accidents), secondary (reduction of severity of injury) and tertiary (reduction in frequency and severity of consequences resulting from an accident). With the addition of 10 countermeasures of William Haddon for the accident occurrence, interventions may be performed at any level of accident prevention
(10). Due to well-developed prevention program, Sweden reached very low rate of children injuries in 1980s. Well-conducted and thorough research, and data collection on the most common causes and injuries, followed by a study on the implementation of proposed prevention measures were later regulated by the law $(10,11)$. Moreover, Sweden is now one of a few countries that has chosen to follow World Health Organization (WHO) recommendations for security, preventive measures and recommendations for the organization of the national multi-sectoral security promotion program $(11,12)$. The approach to the prevention of the unintentional accidents is elaborated in the "3E" (education, enforcement, engineering) model, which is also within the Haddon matrix framework. Significant influence should also be provided by homecare services and pediatric nurses, who provide education on the prevention of child injuries, as well as possible improvements in the securityof home environment (10).

In Croatia, the preventive measures that have been issued and implemented by the Croatian Ministry of Health in cooperation with the Ministry of Social Policy and Youth follow the recommendations of the WHO. There is also a National action plan for the rights and interest of children that addresses the prevention of accidents and the reduction of child mortality in line with the above-mentioned "3E" strategy. It is implemented through the National program for prevention of child injury for the period 2006-2012 (13), while the National Strategy on the Rights of Children in the Republic of Croatia for the period 2014-2020 was adopted in the 2014 (14). An example is the idea of establishing an internet social network, which would enable children, parents and other caretakers to connect and receive the necessary information on children accidents and consequent injuries (15). The European Report on the Safety of Children in Croatia, published in June 2012, ranks Croatia, with a total of 29.5 points, as an average rating and a satisfactory state of security for children with 12 other countries, while the highest ranks Finland with 45 points and the lowest is Greece with 14.5 points (16). Currently, education of parents in Croatia is provided mostly by primary health care professionals due to the most often contact with the parents. However, there is also a potential problem of insufficient, incomplete and poor education and knowledge in some categories of healthcare workers 
(17) which they need to renew (6). Most importantly, parents should pay attention to possible factors that could provoke accidents in their preschool children. Consequently, it is important to install safety fences in nurseries, beds, windows and stairs (to ensure the prevention from falls from height and thus possible fractures), to store medicine/chemicals out-of-reach (to prevent children from poisoning and overdosing), to install smoke/fire detectors (to prevent children from poisoning by carbon monoxide), to install protective covers on electrical sockets (prevention of electrical shock and burns in children), to avoid/remove toys with small items (to prevent suffocation), to keep sharp objects out-of-reach (to prevent cuts), to reduce the water heater temperature (to prevent burns) and to remove plastic bags out of children's reach (to prevent suffocation) $(1,2,4,5)$. It is also important to obtain compliance of the child, to nurture good relations within the family and to teach the child about the injuries and their consequences $(3,18)$.

The objective of this study was to explore the prevalence and the type of injuries in preschool children from the Županja area as well as to explore the parental behavior regarding injury prevention and to investigate the interconnections between these variables.

\section{SUBJECTS AND METHODS}

This cross-sectional study was conducted in April 2015 in the Županja area in the kindergarten "Maslačak" and in the pediatric outpatient clinics within the Županja Health Center. The study was approved by the Ethics Committee of the Faculty of Medicine Osijek. The participants were parents of preschool children who signed the informed consent to participate in the study after which they filled out an anonymous questionnaire. A total of 300 questionnaires was distributed to the convenient sample of parents of preschool children from the Županja area. The response rate was 79.6\% (239/300), while $8.8 \%$ (21/239) of questionnaires were omitted from the final statistical analysis since they were not fully/correctly fulfilled. According to the 2011 census of 841 preschool children in the town of Županja, it can be argued that a sample of parents in this study covered about $25.9 \%$ of parents of preschool children from that area (19).

The questionnaire consisted of sociodemographic questions (gender, age, parents' educational level, working status and marital status, place of family residence, number of members in the household, number, gender and age of the children in the family), questions concerning parental attitudes and behaviors regarding the possibility of accident prevention and questions regarding previous accidentsin preschool children and the description of the severity of those injuries.

\section{Statistical methods}

Descriptive statistical methods were used to describe the frequency distribution of the explored variables. All variables were tested for the normality of distribution by the Kolmogorov - Smirnov test. The mean values of the continuous variables were expressed as arithmetic mean and the standard deviation for variables that were distributed normally. The categorical variables were described in absolute and relative frequencies. To determine the difference between the proportions between the two independent samples $\chi^{2}$-test was used. The significance of differences determined by statistical testing was set at $p<0.05$. In the data processing, the originally written database programs and Statistica for Windows 2010 software (version 10.0, StatSoft Inc., Tulsa, OK) were used.

\section{RESULTS}

The study showed that among all participants, $17.4 \%$ were fathers and $82.6 \%$ were mothers. Average age of the participants was $34.4 \pm 6.0$ years. Regarding the frequency of injuries in their preschool children, $69.7 \%$ of the participants stated that their preschool child did not experience any type of accident, while $30.3 \%$ of the participants stated that their preschool child had some type of accident. Furthermore, according to the category of sustained injury, $86.4 \%$ of the participants reported minor injury of their children (injuries that were not life threatening or did not leave permanent effects on the body) while 9.1\% of the participants reported moderate injuries of their children (possible life-threatening injuries with possible consequences that did not occur). Only $4.5 \%$ of the participants reported serious injury of their preschool children (life-threatening injuries with permanent consequences).

The Table 1 shows association between sociodemographic and socioeconomic characteristics of the participants and the frequency of injuries of their preschool children. 


\begin{tabular}{|c|c|c|c|c|c|}
\hline \multicolumn{2}{|c|}{$\begin{array}{l}\text { Sociodemographic and socioeconomic characteristics } \\
\text { of the parents }\end{array}$} & \multicolumn{2}{|c|}{$\begin{array}{c}\text { Children's injuries } \\
\mathrm{N}(\%)\end{array}$} & \multirow[t]{2}{*}{ Total } & \multirow[t]{2}{*}{$p^{*}$} \\
\hline & & \multirow{2}{*}{$\begin{array}{c}\text { YES } \\
11(16.7) \\
\end{array}$} & NO & & \\
\hline \multirow{4}{*}{ Age group } & $20-27$ years & & $15(9.9)$ & $26(11.9)$ & \multirow{4}{*}{0.48} \\
\hline & $28-35$ years & $28(42.4)$ & $66(43.4)$ & $94(43.1)$ & \\
\hline & $36-43$ years & $23(34.8)$ & $63(41.4)$ & $86(39.4)$ & \\
\hline & $44-50$ years & $4(6.1)$ & $8(5.3)$ & $12(5.5)$ & \\
\hline \multirow{3}{*}{ Educational level } & Primary education & $2(3.0)$ & $7(4.6)$ & $9(4.1)$ & \multirow{3}{*}{0.770} \\
\hline & Secondary education & $45(68.2)$ & $96(63.2)$ & $141(64.7)$ & \\
\hline & University education & $19(28.8)$ & $49(32.2)$ & $68(31.2)$ & \\
\hline \multirow{3}{*}{ Working status } & Employed & $38(57.6)$ & $96(63.2)$ & $134(61.5)$ & \multirow{3}{*}{0.49} \\
\hline & Unemployed & $28(42.4)$ & $54(35.5)$ & $82(37.6)$ & \\
\hline & Retired & $0(0.0)$ & $2(1.3)$ & $2(0.9)$ & \\
\hline \multirow{3}{*}{ Marital status } & Married & $62(93.9)$ & $144(94.7)$ & $206(94.5)$ & \multirow{3}{*}{0.218} \\
\hline & Divorced & $4(6.1)$ & $4(2.6)$ & $8(3.7)$ & \\
\hline & Never been married & $0(0.0)$ & $4(2.6)$ & $4(1.8)$ & \\
\hline \multirow[b]{2}{*}{ Place of residence } & Town & $44(66.7)$ & $107(70.4)$ & $151(69.3)$ & \multirow{2}{*}{0.633} \\
\hline & Village & $22(33.3)$ & $45(29.6)$ & $67(30.7)$ & \\
\hline \multirow[b]{2}{*}{ Type of living space } & Rented apartment or house & $7(10.6)$ & $23(15.1)$ & $30(13.8)$ & \multirow{2}{*}{0.40} \\
\hline & Own apartment or house & $59(89.4)$ & $129(84.9)$ & $188(86.2)$ & \\
\hline \multirow{4}{*}{$\begin{array}{c}\text { Number of } \\
\text { family members }\end{array}$} & 3 members & $9(13.6)$ & $28(18.4)$ & $37(17.0)$ & \multirow{4}{*}{0.61} \\
\hline & 4 members & $31(47.0)$ & $62(40.8)$ & $93(42.7)$ & \\
\hline & 5 members & $16(24.2)$ & $44(28.9)$ & $60(27.5)$ & \\
\hline & 6 members and more & $10(15.2)$ & $18(11.8)$ & $28(12.8)$ & \\
\hline \multirow{3}{*}{$\begin{array}{l}\text { Number of children } \\
\text { in the family }\end{array}$} & One child & $12(18.2)$ & $41(27.0)$ & $53(24.3)$ & \multirow{3}{*}{0.372} \\
\hline & Two children & $33(50.0)$ & $65(42.8)$ & $98(45.0)$ & \\
\hline & Three and more & $21(31.8)$ & $46(30.3)$ & $67(30.7)$ & \\
\hline \multirow[b]{2}{*}{ Family by child's age } & Just preschool children & $32(48.5)$ & $90(59.2)$ & $122(56.0)$ & \multirow{2}{*}{0.181} \\
\hline & Preschool and school children & $34(51.5)$ & $62(40.8)$ & $96(44.0)$ & \\
\hline \multirow{3}{*}{ Family by child's gender } & Boys only & $16(24.2)$ & $41(27.0)$ & $57(26.1)$ & \multirow{3}{*}{0.22} \\
\hline & Girls only & $11(16.7)$ & $39(25.7)$ & $50(22.9)$ & \\
\hline & Boys and girls & $39(59.1)$ & $72(47.4)$ & $111(50.9)$ & \\
\hline \multirow{5}{*}{$\begin{array}{c}\text { Self-perceived } \\
\text { socioeconomic status }\end{array}$} & Significantly under-average & $0(0.0)$ & $3(2.0)$ & $3(1.4)$ & \multirow{5}{*}{0.346} \\
\hline & Slightly under-average & $10(15.2)$ & $13(8.6)$ & $23(10.6)$ & \\
\hline & Average & $43(65.2)$ & $101(66.4)$ & 144 (66.1) & \\
\hline & Slightly over-average & $11(16.7)$ & $33(21.7)$ & $44(20.2)$ & \\
\hline & Significantly over-average & $2(3.0)$ & $2(1.3)$ & $4(1.8)$ & \\
\hline
\end{tabular}

Table 1. Association between parents' sociodemographic and socioeconomic characteristics and the frequency of injuries in their preschool children

$\mathrm{N}$ - number of participants; ${ }^{*} \chi^{2}$-test 
The Table 2 shows parents' behavior regarding injury prevention in their children.

Table 2. Parents' behavior regarding child injury prevention

\begin{tabular}{|c|c|c|}
\hline \multirow[t]{2}{*}{ Questions related to the parents' behavior regarding child injury prevention } & \multicolumn{2}{|c|}{$\begin{array}{l}\text { Participant's answer } \\
\text { N (\%) }\end{array}$} \\
\hline & YES & N0 \\
\hline Is there a bed in which your preschool child is sleeping with a security fence preventing falling? & $137(62.8)$ & $81(37.2)$ \\
\hline $\begin{array}{l}\text { Do you have a security barrier that prevents a child from entering the stairs without adult } \\
\text { supervision? }\end{array}$ & $96(44.0)$ & $\begin{array}{c}122 \\
(56.0)\end{array}$ \\
\hline $\begin{array}{l}\text { Do you have a security barrier that prevents a child from accessing the windows of your house } \\
\text { without adult supervision? }\end{array}$ & $67(30.7)$ & $\begin{array}{c}151 \\
(69.3)\end{array}$ \\
\hline Do you have installed a smoke / fire detector in your home? & $10(4.6)$ & $\begin{array}{l}208 \\
(95.4)\end{array}$ \\
\hline $\begin{array}{l}\text { Do you keep medicine, alcohol, detergents and all other potentially toxic substances in the areas } \\
\text { that are not available to the children? }\end{array}$ & $177(81.2)$ & $41(18.8)$ \\
\hline Do you store sharp objects (knives, scissors, tools) in places that are not available to the children? & $175(80.3)$ & $43(19.7)$ \\
\hline $\begin{array}{l}\text { Are electrical sockets in your home protected with protective covers that prevent access to the } \\
\text { children? }\end{array}$ & $168(77.1)$ & $50(22.9)$ \\
\hline $\begin{array}{l}\text { Are children in your home in any way disabled from accessing the high temperature surfaces (oven, } \\
\text { stove)? }\end{array}$ & $126(57.8)$ & $92(42.2)$ \\
\hline Does your child play with tiny toys that can potentially cause suffocation? & $74(33.9)$ & $\begin{array}{c}144 \\
(66.1)\end{array}$ \\
\hline
\end{tabular}

$\mathrm{N}$ - number of participants

The Table 3 shows association between parents' behavior related to injury prevention and the frequency of injuries of their preschool children.

Table 3. Association between parents' behavior related to injury prevention and the frequency of injuries of their preschool children

\begin{tabular}{|c|c|c|c|c|c|}
\hline \multirow{2}{*}{ Parents' behavior related to injury prevention } & \multicolumn{3}{|c|}{$\begin{array}{c}\text { Children's injuries } \\
\mathrm{N}(\%)\end{array}$} & \multirow[t]{2}{*}{ Total } & \multirow{2}{*}{$p^{*}$} \\
\hline & & YES & NO & & \\
\hline \multirow[t]{2}{*}{$\begin{array}{l}\text { The existence of a security fence on the bed where } \\
\text { the child is sleeping }\end{array}$} & YES & $39(59.1)$ & $98(64.5)$ & $137(62.8)$ & \multirow[b]{2}{*}{0.542} \\
\hline & N0 & $27(40.9)$ & $54(35.5)$ & $81(37.2)$ & \\
\hline \multirow[t]{2}{*}{$\begin{array}{l}\text { The existence of a security barrier that prevents a } \\
\text { child from accessing the steps without adult } \\
\text { supervision }\end{array}$} & YES & $26(39.4)$ & $70(46.1)$ & $96(44.0)$ & \multirow{2}{*}{0.377} \\
\hline & NO & $40(60.6)$ & $82(53.9)$ & $122(56.0)$ & \\
\hline \multirow[t]{2}{*}{$\begin{array}{l}\text { The existence of a security barrier that prevents a } \\
\text { child from accessing the residential building } \\
\text { windows without adult supervision }\end{array}$} & YES & $20(30.3)$ & $47(30.9)$ & $67(30.7)$ & \multirow[t]{2}{*}{$>0.999$} \\
\hline & NO & $46(69.7)$ & $105(69.1)$ & $151(69.3)$ & \\
\hline
\end{tabular}


Matić I, Kovačević J, Miškulin I, Pavlović N, Miškulin M. Injuries in preschool children and the possibilities of their prevention.Zdravstveni glasnik. 2021;7(2):32-41.

\begin{tabular}{|c|c|c|c|c|c|}
\hline \multirow[t]{2}{*}{ Installed smoke/fire detector in a dwelling } & VES & $2(3.0)$ & $8(5.3)$ & $10(4.6)$ & \multirow{2}{*}{0.727} \\
\hline & NO & $64(97.0)$ & $144(94.7)$ & $208(95.4)$ & \\
\hline \multirow{2}{*}{$\begin{array}{l}\text { Keeping medicine, alcohol, detergents and other } \\
\text { potentially toxic substances in the areas that are } \\
\text { not available to the children }\end{array}$} & YES & $56(84.8)$ & $121(79.6)$ & $177(81.2)$ & \multirow{2}{*}{0.452} \\
\hline & NO & $10(15.2)$ & $31(20.4)$ & $41(18.8)$ & \\
\hline \multirow[t]{2}{*}{$\begin{array}{l}\text { Keeping sharp objects (knives, scissors, tools) in } \\
\text { places that are not available to the children }\end{array}$} & YES & $52(78.8)$ & $123(80.9)$ & $175(80.3)$ & \multirow{2}{*}{0.853} \\
\hline & NO & $14(21.2)$ & $29(19.1)$ & $43(19.7)$ & \\
\hline \multirow{2}{*}{$\begin{array}{l}\text { The existence of electrical sockets protected by } \\
\text { protective covers that prevent access to the } \\
\text { children }\end{array}$} & YES & $50(75.8)$ & $118(77.6)$ & $168(77.1)$ & \multirow{2}{*}{0.861} \\
\hline & NO & $16(24.2)$ & $34(22.4)$ & $50(22.9)$ & \\
\hline \multirow[t]{2}{*}{$\begin{array}{l}\text { Children are disabled from accessing the high } \\
\text { temperature surfaces (oven, stove) }\end{array}$} & YES & $36(54.5)$ & $90(59.2)$ & $126(57.8)$ & \multirow{2}{*}{0.553} \\
\hline & NO & $30(45.5)$ & $62(40.8)$ & $92(42.2)$ & \\
\hline \multirow[t]{2}{*}{$\begin{array}{l}\text { Child playing with tiny toys that can potentially } \\
\text { cause suffocation }\end{array}$} & YES & $28(42.4)$ & $46(30.3)$ & $74(33.9)$ & \multirow{2}{*}{0.089} \\
\hline & NO & $38(57.6)$ & $106(69.7)$ & $144(66.1)$ & \\
\hline
\end{tabular}

$\mathrm{N}$ - number of participants; ${ }^{*} \chi^{2}$-test

\section{Discussion}

This study consisted of predominately female participants. The reason for such gender distribution probably lies in the fact that care for preschoolers in the Republic of Croatia is usually provided by the mothers. In this study, most of the participants were middle-aged and are expected to provide an appropriate care for their children given the circumstances and life opportunities. Interestingly, results showed higher proportion of child injuries in the youngest age group of parents than in the oldest age group of parents, although not significantly. Young parents appear to be riskier group for child injuries than old ones, what might not be expected since younger people in physical sense can respond better to the challenges of childhood playfulness and activities. These results suggest that physical health and abilities are not crucial in preventing injuries in children, but rather parenting experience and parents' preventative approach.
Other studies found lower level of education of the parents to be associated with more severe and more frequent injuries in children $(5,16,18)$. Other studies also suggest that the level of education should be observed together with other factors that could affect the occurrence and frequency of injury, such as socioeconomic status $(18,20)$. This study has not determined association between education level of the parents and injuries in preschool children. Regarding the working status of the participants, it is reasonable to assume how participants who are employed have less time for their children depending on their working time and fatigue, however, study results have not determined association between working status of the parents and injuries of their preschool children. With regard to the marital status of the parents, others determined difficulties for single parents without adequate support in achieving child accident prevention (3). However, this study found no association between marital status of the parents and injuries of their preschoolers. Study found no 
significant association between urban or rural place of residence and frequency of injuries in preschool children. Regarding the ownership of the living space, the advantages of one's own living spaceare large in comparison to rented apartment or house, because people can adapt their space in a way to prevent possible accidents in children $(2,5,18,21)$. However, this study did not determine the association between the type of the living space regarding ownership and injuries in children. When considering the number of family members, the most common were families with four family members, but the study did not determine association between the number of family members and injuries in children. Furthermore, number of children in the family also showed no association with the frequency of child injuries, although one might assume that having more children would be associated with more accidents and greater difficulties to prevent injuries in children. The incidence of child injuries in families with only preschoolers and families with both preschoolers and schoolers was almost equal. With regard to children's gender, other studies found male children to be more susceptible to injuries due to the type of games and the way of parenting, while female children tend to gentle games and different type of parenting (2,3). However, this study found no association of children's gender and injuries. Other studies found families with significantly low socioeconomic status to have a significant incidence of child injuries $(3,10,11,18)$, but this study found no association between parents' socioeconomic status and children's injuries. Results suggest that different populations have different sociodemographic and socioeconomic characteristics relevant for child injury prevention. Significant predicting factors for knowledge, attitude and self-efficacy in rural Egyptian mothers were their age, educational level and previous occurrence of home injuries (22). This study suggests that in the investigated population of parents some other factors, different from the usually explored sociodemographic and socioeconomic factors, may influence child injuries.This study did not determine significant differences in frequency of injuries in preschool children in relation to parental behavior related to injury prevention. The worst result for investigated parental behaviors was obtained for the (none) existence of smoke/fire detectors in the residence. These results indicate how much participants fall behind other European countries in preventing accidents of preschool children (12), but they are still higher (4.6\%) than in a survey conducted in Mexico in 2002, which found only $0.04 \%$ of the participants with installed smoke/fire detector (23). A study from UK found that $91.2 \%$ of parents kept their medicine in places unreachable to children (24), which is larger proportion than found in this study. The same study also found $74.4 \%$ of parents having window protection (24), while this proportion was much lower in this study (30.7\%). In this study, parents paid most attention to these preventive measures: keeping toxic substances away from children's reach (81.2\%), keeping sharp objects from children's reach $(80.3 \%)$ and the protection of electrical sockets (77.1\%). Other investigated preventive strategies were less employed suggesting the need for education of parents in order to improve the knowledge about children's safety. Therefore, in the prevention of accidents of preschool children an important roleplay the health professionals (doctors, nurses, as well as nurses in kindergarten and schools), state legislatures (template and laws drafting), specially formed working groups within health care and education, the media as well as business companies (10).

This study could be expanded in several directions because it did not cover all segments of preschool children's accident and their prevention. Future studies might include injuries in preschoolers outside of residence, because this research was primarily focused on injuries within a residential building. Bites inflicted by pets and other animals as well as falls were excluded from this study (25). Also, a more detailed characteristics of parents/guardians of the preschoolers could be obtained, in terms of free time, as well as psychophysical condition that could affect the accident prevention, but also (in)direct cause of possible accident. Another item that could be a valuable source of information is the relationship between parents/guardians. The main limitation of this study is associated with self-reported data and honesty of the participants. Another limitation was that the research was conducted in the small local region of Croatia. Therefore, these results do not present the behavior of all parents of preschoolers in Croatia. However, data are significant for further monitoring of parents' education about their children's safety and accident prevention capacities. 


\section{CONCLUSION}

Injuries in preschool children are a major public health problem today. This study showed that $30.3 \%$ of participants from the Županja area reported their preschool children sustained some kind of injury. According to the severity of the injury, they were most commonly minor injuries. Parents of preschool children showed satisfactory behavior in terms of preventing injuries. In most of the examined behaviors (6 of 9) parents showed adequate accident prevention behavior. In three examined behaviors (the existence of a security barrier that prevents access to the stairs, the existence of a security barrier that prevents access to the windows and the installation of smoke detectors) parents have shown inadequate behavior which implies the need for their additional education. In conclusion, this study can serve as a database for future investigations related to accidents of preschool children and the possibilities of their prevention. Additional studies are needed to better understand parental behavior in relation to the prevention of their children's accidents.

\section{REFERENCES}

1. Schmertmann M, Williamson A, Black D, Wilson L. Risk factors for unintentional poisoning in children aged 1-3 years in NSW Australia: a case control study. BMC Pediatrics. 2013;13:88.

2. Qiu X, Wacharasin C, Deoisres W, Yu J, Zheng Q. Characteristics and predictors of home injury hazards among toddlers in Wenzhou, China: a community - based cross - sectional study. BMC Public Health. 2014;14:638.

3. Schwebel D, Davis A, O'Neal E. Child Pedestrian Injury: A Review of Behavioral Risks and Preventive Strategies. Am J Lifestyle Med. 2012;6:292-302.

4. Khambalia A, Joshi P, Brussoni M, Raina P, Morrongiello B, Macarthur C. Risk factors for unintentional injuries due to falls in children aged 06 years: a systematic review. Inj Prev. 2006;12:378-81.

5. Wynn P, Stewart J, Kumar A, Clacy R, Coffey F, Cooper N, et al. Keeping children safe at home: protocol for a case - control study of modifiable risk factors for scalds. Inj Prev. 2014;20:e11.

6. Mujkić A. Accident prevention and preschool child safety improvement. Zagreb: UNICEF Office for Croatia, 2010.

7. Bralić I. The role of primary healthcare paediatricians in prevention of accidents involving children. Paediatr Croat. 2015;59(Suppl1):212-6.

8. Morromgiello B. Preventing Unintentional Injuries to Young Children in the Home: Understanding and Influencing Parents' Safety Practices. Child Dev. Perspect. 2018;0:1-6.

9. Zhou HZ, Fan LJ, Wu CA, Luo AF, Mo CQ, $\mathrm{He} \mathrm{GH}$, et al. Understanding the associations among parents teaching safety rules to children, safety behaviors and unintentional injuries in Chinese preschool children. Prev. Med. 2019;118:98-103.

10. Towner E, Scott I. Chapter 1. Child injuries in context. In: Peden M,Oyegbite K, Ozanne-Smith J, Hyder AA, Branche C, Rahman AKMF, Rivara F, Bartolomeos K. Eds. World report on child injury prevention. Geneva: WHO Press, 2008;1-22.

11. Sengoelge $\mathrm{M}$, Elling $\mathrm{B}$, Laflamme L, Hasselberg M. Country - level economic disparity and child mortality related to housing and injuries: a study in 26 European countries. Inj Prev. 2013;19:311-5.

12. MacKay M, Vincenten J. Child Safety Report Card 2012: Europe Summary for 31 Countries. Birmingham: European Child Safety Alliance, Eurosafe, 2012.

13. The government of the Republic of Croatia- Ministry of social politics and youth. National plan of activities for the rights and interests of children from 2006 until 2012.

14. The government of the Republic of Croatia - Ministry of social politics and youth. National plan of activities for the rights and interests of children from 2014 until 2020

15. Antabak A, Mađarić M, Stilinović M, Papeš D, Luetić T. Prevention of injuries in children - Model of internet social network. Paediatr Croat. 2015;59:1858.

16. Brkić Biloš I, Kralj V, Pavić Šimetin I, Petrović G, Gverović Antunica A. Izvješće o sigurnosti djece - Child Safety Report Card. Hrvatski časopis za javno zdravstvo. 2012;8(31):84-9.

17. Crnica V, Mujkić A, Young T, Miškulin M, Peek - Asa C. Healthcare Providers' Knowledge, Attitudes and Counselling on Injury Prevention for Preschool Children in Croatia. Matern Child Health J. 2013;17:1718-24.

18. Ablewhite J, Peel I, McDaid L, Hawkins A, Goodenough T, Deave T, et al. Parental perceptions of barriers and facilitators to preventing child unintentional injuries within the home: a qualitative study. BMC Public Health. 2015;15:280. 
19. Croatia Bureau of Statistics. Census 2011. Population by gender and age.

20. Morrongiello B, Ondejko L, Littlejohn A. Understanding Toddlers' In-Home Injuries: I. Context, Correlates and Determinants. J Pediatr Psychol. 2004;29:415-31.

21. Huljak M, Brkić Biloš I. Traffic accidents in children 2013. Zagreb: Croatian Institute of Public Health, 2013.

22. El Seifi OS, Mortada EM, Abdo NM. Effect of community-based intervention on knowledge, attitude, and self-efficacy toward home injuries among Egyptian rural mothers having preschool children. PloS One.2018;13:e0198964.

23. Mock C, Arreola Rissa C, Trevino Perez R, Almazan Saavedra V, Enrique Zozaya J, Gonzalez Solis $\mathrm{R}$, et al. Childhood injury prevention practices by parents in Mexico. Inj Prev. 2002;8:303-5.

24. Evans A, Kohli S. Socioeconomic status and the prevention of child home injuries: a survey of parents of preschool children. Inj Prev. 1997;3:29-34.

25. Janev Holcer N, Brkić Biloš I, Jurić F, Rešić A, Vugrinčić M. Čimbenici rizika i ozljede djece pri obavljanju poljoprivrednih poslova u Požeškoslavonskoj županiji. Paediatr Croat. 2014;58:190-5 


\title{
OZLJEDE U DJECE PREDŠKOLSKE DOBI I MOGUĆNOSTI NJIHOVA SPRJEČAVANJA
}

\author{
Ivon Matić ${ }^{1}$, Jelena Kovačević ${ }^{2},{ }^{3}$, Ivan Miškulin ${ }^{2}$, Nika Pavlović ${ }^{2}$ Maja Miškulin ${ }^{2 *}$ \\ ${ }^{1}$ Županja Health Center, Županja, Croatia \\ ${ }^{2}$ Josip Juraj Strossmayer University of Osijek, Faculty of Medicine Osijek, Osijek, Croatia \\ ${ }^{3}$ Institute of emergency medicine of the Vukovar-Srijem County, Vinkovci, Croatia
}

\section{SAŽETAK}

UVOD: Ozljede su kod djece predškolske dobi jedan od vodećih uzroka morbiditeta i mortaliteta u današnjem svijetu.

CILJ: Istražite prevalenciju i vrstu ozljeda u djece predškolske dobi, kao i ponašanje roditelja u vezi s prevencijom ozljeda, te ispitati međusobne povezanosti između ovih varijabli.

ISPITANICI I METODE: Presječno istraživanje obuhvatilo je 218 roditelja predškolske djece s područja Županje, u istočnoj Hrvatskoj, koji su tijekom travnja 2015. godine ispunili anonimni upitnik koji se sastojao od pitanja u vezi sa sociodemografskim i socioekonomskim pokazateljima obitelji te ponašanjem ispitanika $u$ vezi s prevencijom ozljeda.

REZULTATI: Bilo je 30,3\% roditelja čija su djeca predškolske dobi pretrpjela ozljedu, a 86,4\% od njih su pretrpjeli lakšu ozljedu. U većini ispitivanih roditeljskih ponašanja roditelji su pokazali odgovarajuće ponašanje u pogledu sprječavanja nesreća, dok su u tri ispitivana ponašanja (postojanje sigurnosne barijere koja sprječava pristup stepenicama, postojanje sigurnosne barijere koja sprječava pristup prozorima $\mathrm{i}$ ugradnja detektora dima) roditelji pokazali neadekvatno ponašanje što ukazuje na potrebu za njihovim dodatnim obrazovanjem.

ZAKLJUČAK: Ovo istraživanje može poslužiti kao baza podataka za buduća istraživanja nesreća predškolske djece i mogućnosti njihove prevencije. Potrebna su dodatna istraživanja kako bi se razumjelo ponašanje roditelja u vezi s prevencijom nesreća njihove djece.

Ključne riječi: ozljeda, predškolsko dijete, roditelji, prevencija, Hrvatska

Corresponding author:

Professor Maja Miškulin, MD, PhD, specialist in epidemiology and health ecology

Josip Juraj Strossmayer University of Osijek

Faculty of Medicine Osijek

Josipa Huttlera 4, 31000 Osijek, Croatia

Tel.: +385912241438

E-mail: maja.miskulin@mefos.hr 